\title{
The Status of Agricultural Land as a Natural Resource and the Process of Serbia's Accession to the EU
}

\author{
Bozo Draskovic \\ Institute of Economic Sciences, Belgrade \\ bozo.draskovic@ien.bg.ac.rs \\ Mihajlo Djukic \\ Institute of Economic Sciences, Belgrade \\ mihajlo.djukic@ien.bg.ac.rs
}

\author{
Malisa Djukic \\ Belgrade Banking Academy, Belgrade \\ djukicmalisa@hotmail.com
}

\begin{abstract}
This article discusses one specific aspect of the process of Serbia's EU Accession which refers to liberalisation of the transfer of economic property rights over natural resources, particularly agricultural land. The underlying principles of the free market economy assume free movement of goods, capital and labour. However, there are two existing approaches when analysing transfer of property rights over agricultural land as a natural resource. The first one insists on full liberalisation of the transfer of ownership rights in this area, while the second approach assumes limiting or imposing certain restrictions through national legislation on the free transfer of property rights over agricultural land as a limited national resource and national wealth. Experiences of applying these two approaches within EU member states differ from full liberalisation to significant restrictions on the freedom of agricultural land ownership transfer. In the process of accession negotiations with the $E U$ and in line with a proclaimed interest to join the World Trade Organisation, Serbia has to deal with the issues of liberalisation of trade of agricultural products as well as other national resources including agricultural land. Since the EU regulations do not have any specific requirement in terms of the adoption of a completely liberal approach, it is up to Serbia to decide which model is the most appropriate, considering its own interests. The article defines and discusses arguments which strongly speak in favour of imposing limitations to the full liberalisation of the transfer of property rights over agricultural land as a natural resource in Serbia.
\end{abstract}

Keywords: agricultural land, ownership rights, transfer, Serbia's EU accession

\section{Introduction}

Agricultural land, in general, is assumed to be a different factor of production when compared to other factors such as labour or capital. Physical assets of created capital in the form of construction and infrastructure located in a particular market could be easily bought or sold, while market location remains the same. In the form of goods, they do not move from the market where they are produced to the market where they 
could be exploited. Financial assets, on the other hand, represent the form of created capital which, in a developed global market, easily moves from one to another local market within a couple of minutes depending on the speed of issuing orders for transfer. Labour force is also a relatively transferable factor of production whose ability to be transferred mainly depends on the level of education attained by an individual. People with higher education and greater expertise and experience easily change employment, at the same time changing their physical locations/countries. As the educational level and skills of an individual decrease, labour factor transferability within a single market (such as the EU) decreases as well. As pointed out by Becker who divided human capital into general and specific, general human capital holds 'transferable' characteristics across jobs, firms and industry. Therefore, it is relatively easy that the general human capital embedded in an individual person transfers to different industries (Becker, 1964). Knowledge and abilities are said to be general if it is possible to use them in a variety of activities and if they are easily transferable from one employer to another without any significant loss of value (Laroche et al., 1999). Unlike the other factors of production, agricultural land is a fixed resource, attached to the local market and country of its location. It can also be defined as inherited or natural capital. Similarly to other fixed assets, it does not change its location being only subject to the change of ownership with regard to national or regional/subnational regulations. Change of ownership within a country is mainly de-regulated with some anti-monopolistic restrictions. Change of ownership of agricultural land, on the other hand, as well as invoking questions of eligibility for non-residents, is usually regulated and restricted by local legislation. A majority of the states reviewed discriminate against foreign ownership and, less frequently, foreign use of land through various restrictions and regulations. These can range from an outright ban to a simple requirement that notice of foreign ownership be given to the relevant authorities. Such policies can apply to all of the land within a state's boundaries, or only to land in certain areas, of a particular nature or designated for a particular use, or to a combination of these (Hodgson, 1999).

In a perfectly liberal, laissez-faire concept, market economy prices of agricultural land depend on derived demand. In fact, prices depend on supply and demand for goods that are produced in the process that includes exploitation of agricultural land as natural capital. If prices of the agricultural products grow, prices of land increase as well, and vice versa. Common patterns of changes in supply and demand are relatively limited when it comes to the explanation of price changes of agricultural land. Limitation occurs as a result of the fact that aggregate supply of agricultural land as a natural resource or natural capital is fixed. Changes occur concerning the way that natural capital is used and depend on the application of different technologies and innovations during the cultivation process. A rational question arises whether it is theoretically and methodologically acceptable to consider agricultural land exclusively from the point of view regularly applied in case of other factors of production.

As has been already stated, the supply of agricultural land within the "old", developed EU member states is naturally limited. The market has already stabilised and, in fact, within these countries, transactions related to the sale of agricultural land are almost marginal. The additional supply of agricultural land could come from associated or new EU members, as well as future member countries such as Serbia, Montenegro, Bosnia and Herzegovina (-H), Macedonia and Albania. As noted by Antonelli et al. (2015), if we look at the European countries most targeted by EU investors, the Russian Federation occupies first position followed by Ukraine, Bulgaria, Romania and 
Lithuania. Land acquisitions in these countries are pursued by Sweden followed by Denmark, France, Bulgaria, Finland and Germany. The majority of these land deals, approximately 72 per cent, are meant to produce flexible crops, which can be used for food or biofuel production (such as rapeseed, sugar beet, soybean and sunflower).

The aim of this paper is to analyse the state of the agricultural land market in Serbia in light of the current institutional and policy framework in Serbia and the EU. The core argument of the paper deals with the effects of potential liberalisation of the transfer of property rights over agricultural land. It will be analysed in terms of the current state of agricultural land as a market determinant in Serbia as well as the relevance of the issues related to transfer of agricultural land ownership rights. The analysis includes the presentation of comparative perspectives of the agricultural land structure in Serbia and in neighbouring countries, potential effects of liberalisation and justification of the reasons behind limiting property rights. Finally, there will be a brief analysis of the technical part of the EU negotiations as well as experiences of countries that have already entered the EU and had to tackle policy problems similar to those Serbia currently faces. The last part of the paper provides concluding remarks and a list of potential policy options.

\section{Transfer of the agricultural land ownership issue in Serbia - some important aspects}

The Republic of Serbia has a comparative advantage in agriculture. The overall utilised agricultural area in Serbia is 5.092.00o hectares (ha), which account for 57.6 per cent of its territory and around 0.6 ha per capita. Around 82.8 per cent is cultivable, which is above European standards. The ratio of forest and agricultural vegetation (39:61 per cent) is also more favourable than in many European countries (Bogdanov et al., 2007). Additionally, the share of the economically active agricultural population in the overall economically active population amounts to 11.7 per cent, making Serbia one of the leading European countries in this respect (Vehapi and Sabotic, 2015). Agriculture accounts for around 11 per cent of Serbia's GDP, as well as 23 per cent of total exports, and only 7 per cent of the country's imports, creating an annual trade surplus of $\$ 1.2$ billion (Gajic et al., 2017).

In addition to the presence of favourable factors and trade conditions for the development of intensive and competitive agricultural production (Parausic and Cvijanovic, 2014 and Bogdanov et al., 2007), the main advantages are so far related to relatively cheap labour and a wealth in natural resources of a good quality. Agricultural land, similar to other property in the Former Federaral Republic of Yugoslavia, was partly confiscated or nationalised by the state after the Second World War. It has to be noted that the concept applied was quite different compared to other socialist economies, since restrictions related to land market transactions in Serbia were much less strict than in other planned economies (e.g. Albania, Hungary, etc.) allowing farmers to own small parcels of land up to 10ha, although without the option to sell goods at their free will (Lavigne, 1999). Before the post-communist transition process started in 1990, around 80 per cent of the arable land was privately owned. State and social ownership, before privatisation, existed in large agricultural complexes (Draskovic et al. 2011). Therefore, at the beginning of the period of transition in 1990, the state was the largest single land owner. The privatisation process of agricultural land since has been relatively non-transparent, implemented under the conditions of political uncertainty, deep economic and social crises as well as institutional 
deficiencies. As the largest single land owner in the Republic of Serbia, the State posseses more than 50 per cent of the parcels greater than 5ha. Nowadays, approximately 90 per cent of arable land is privately owned and 10 per cent belongs to the government (Export.gov, 2018), which means that on average plots are very small.

The agricultural market in Serbia in general is characterised by very fragmented ownership. As per the Census of Agriculture conducted in 2012, there were 631,555 farms, which covered an area of 3,437 million hectares of agricultural land. The average size of a plot was 5.44 hectares. (Census of Agriculture, 2012). For purposes of comparison, the average area per plot in Denmark is 65 ha, and 152 ha in the Czech Republic (Vehapi and Sabotic, 2015). Among the listed farms, 99.6 per cent were households which covered 84 per cent of the area (Census of Agriculture, 2012).

Such a fragmented ownership structure brings several problems, some of which directly jeopardise the competitiveness of the sector (Simonovic et al., 2017 and Djuricin et al., 2013):

1. Small households are not in a position to apply modern technology nor to follow technological progress, which is the backbone of the development of a modern agrarian economy;

2. Income in small-scale production is not comparable to the income in other sectors, hence influencing demographic problems in rural areas;

3. Low productivity in small-scale production contributes to price increases of agricultural products influencing lower competitiveness

In a research sample that included 14 selected EU countries and Serbia, Parausic and Cvijanovic pointed out that if economic value of agricultural land (measured by value of output) is considered, only Romania has a lower share of rich agricultural households (market value above EUR 100,000) than Serbia (0.3 per cent). The average share in the Netherlands, Germany and France amounts to 53.8, 35.1, and 31.1 per cent respectively. It should be noted that Germany has fewer than half the number of households engaged in agriculture than Serbia, while the average economic value of one household is 23 times greater (Parausic and Cvijanovic, 2014). This is an indication of traditional and extensive agriculture as well as low productivity and insufficient specialisation. Almost one fourth of all employees in Serbia are in agriculture, while Germany has much more competitive agricultural products and a higher volume of agricultural production with only 2.4 per cent of employees in the agricultural sector. High participation of the labour force indicates that it is about low-productive activities (Kuzman et al., 2017).

The EU accession process that started in 2001 imposed a set of different requirements in terms of adjustment of the country's laws to the EU acquis communautaire, particularly Chapter 4 which is related to free movement of capital, and Chapter 11 which covers the Common Agricultural Policy (CAP) rules. This process is also related to the liberalisation of the market for land and abolition of trade barriers. It meant that the private sector could be, in a relatively short period of time, exposed to strong international competition. Limiting property rights over the land is only one of the issues that need to be resolved, being particularly pertinent for policy debate since no EU Directive requires full liberalisation. In that context, it has been a very relevant issue whether Serbian policy makers need to slow down the liberalisation process of the land market with regard to potential consequences in terms of competition or price 
pressures. Liberalisation of property rights is also a subject of political discussions, being considered as national natural wealth and heritage. Attitudes towards ownership restrictions have been quite popular and in line with the rise of populist parties presenting themselves as guardians of the national interest. Taking into account the aforementioned arguments, some countries apply different protectionist measures to prevent foreign citizens buying land. The Czech Republic, Estonia, Latvia, Lithuania, Hungary, Poland and Slovakia, that entered the EU in 2004, were granted transitional periods during which they could maintain existing provisions of their legislation restricting the acquisition of agricultural land or forest, in derogation to the freedom of capital movement. The transitional period amounted to 7 years for the Czech Republic, Estonia, Hungary, Latvia, Lithuania and Slovakia, and 12 years for Poland (Swinnen and Vranken, 2007). The Polish and Hungarian authorities mainly claimed that early removal of existing restrictions would result in unfavourable short-term outcomes, especially if foreigners acquired large portions of rural land. As a result, domestic farmers would not have sufficient land for farming. In 2010, Hungary requested an extension of the transition period by three years (Humblet, 2013). According to the 2013 Land Act the Government took further steps to prevent foreigners from purchasing or cultivating Hungarian lands without direct violation of the EU law. Farmers from the EU may own up to 300 hectares of land, and combined with leased lands they can control up to 1,200 hectares - just as Hungarians are allowed to. However, acquisitions could be prevented by Land Committees made up of local farmers which could reject transactions without any particular reason creating further issues such as the presence of 'pocket contracts' (Boros, 2015).

\section{Agricultural land structure in Serbia and neighboring countries}

Agricultural land as a resource at the global level in relation to the number of inhabitants is an extremely scarce resource. The average agricultural area per capita at the global level is only 0.2 ha. Compared to the world average, Croatia and Slovenia are at this level or even below. Potential EU candidate countries that have lower indicators compared to the global average are Kosovo and Macedonia, which is close to the average global level. Montenegro and B-H are slightly above the world average. Serbia, as shown in Graph 1, has a more than two times higher indicator of area of agricultural land to the number of citizens than the global average, a slightly higher average than the new Eastern European EU member states, Romania and Bulgaria. For Serbia agricultural land, as a national resource, is particularly important since it represents a comparative advantage on which future economic development could be based. Just as Croatia to a large extent depends on tourism or Slovenia to a large extent depends on a strong industry sector, Serbia has the advantage of fertile land, particularly in the northern parts of the country. For that reason, and similar to Hungary and Poland, effective and evidence-based agricultural and ownership policy is of vital importance for the Republic of Serbia.

The fact that Serbia has more fertile land per capita when compared to other countries in the region does not reveal anything about the land ownership distribution, an important segment of agricultural policy planning. As stated above, historically individual ownership of agricultural land in Serbia was not abolished by the Communist authorities after the Second World War. Over 82 per cent of agricultural land was in the hands of small rural owners. This 'fact'-has little credence since in the situation of controlled production and export, as well as limited trade of land and 
Figure 1: Disposable agricultural land (ha per capita)

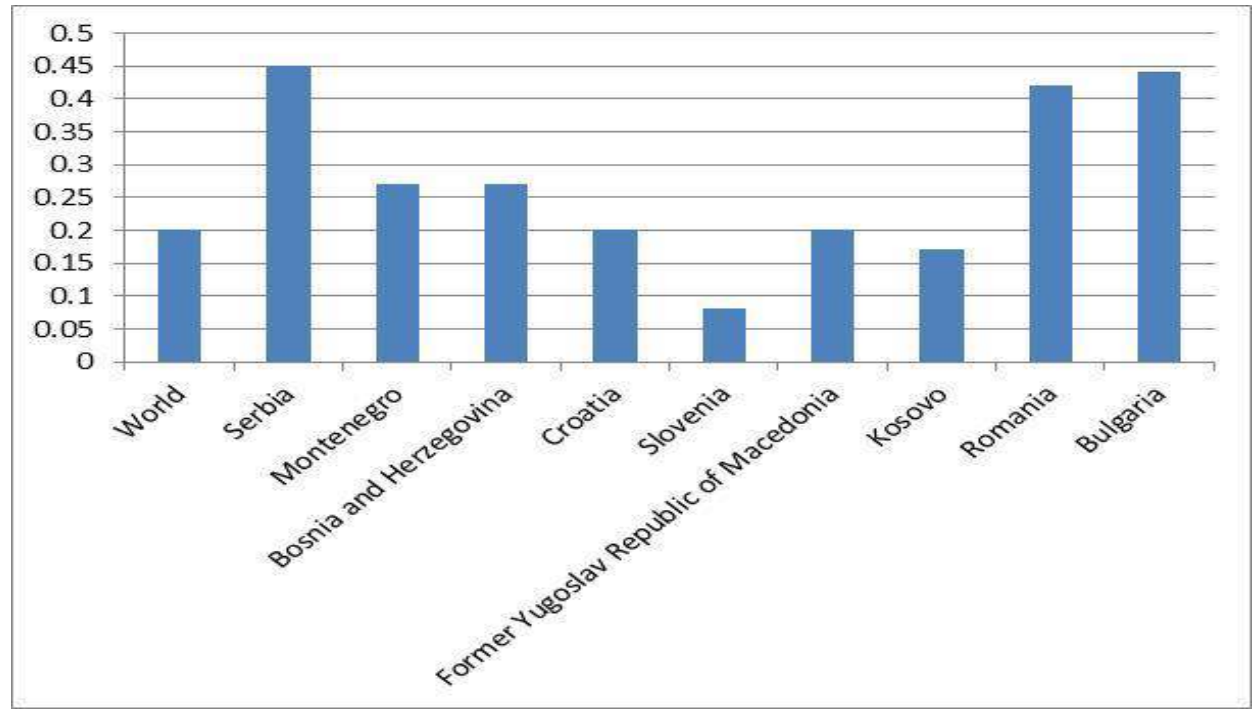

Source: own calculations based on national statistics on the agricultural land and number of citizens (see Djukic, 2017).

agricultural products, private ownership of land could hardly be fully exterted. Private ownership of land was limited to 10 ha in flatland and 20 ha in mountain areas. Part of the complex of agricultural land was concentrated in large agricultural state-owned enterprises. Following the change of the political system in the 1990s, privatisation of large complexes of agricultural land occurred, although into the ownership of private companies, the largest holdings have individually no more than 30,000 ha.

As shown in Table 1, around 76 per cent of the total number of farms in Serbia are less than 5 ha in size, while in the European Union, 67.2 per cent of all farms fall into this category.Farm size between 5 and 20 ha in Serbia accounts for 19.2 per cent of all farms. In the EU, there are 18.4 per cent of farms which fall into this category. In Serbia, farms with a size of more than 2oha account for 3.1 per cent of all farms, which is significantly lower compared to the EU (around 12.3 per cent).

Table 1: Size of the agricultural land ownerships in Serbia and EU

\begin{tabular}{|c|c|c|}
\hline $\begin{array}{l}\text { Size of used } \\
\text { agricultural land }\end{array}$ & $\begin{array}{c}\text { Republic of Serbia per Census } \\
\text { conducted in 2012 (share of farms in } \\
\text { selected category in per cent) }\end{array}$ & $\begin{array}{c}\text { EU - 28 per EUROSTAT data for } \\
\text { 2010 (share of farms in selected } \\
\text { category in per cent) }\end{array}$ \\
\hline$<2$ ha & 47.2 & 47.0 \\
\hline $2-5$ ha & 28.9 & 20.2 \\
\hline $5-10$ ha & 14.1 & 10.9 \\
\hline $10-20$ ha & 5.1 & 7.5 \\
\hline$>20$ ha & 3.1 & 12.3 \\
\hline
\end{tabular}

Source: Statistical Office of the Republic of Serbia and Eurostat

Favourable agricultural land ownership structure is a prerequisite for agricultural land development and competitiveness. It should be noted that the Republic of Serbia has an unfavourable ownership structure. It is based on small and fragmented holdings with an average area of around 5 ha. This is 3 to 4 times smaller than the EU-28 average, implying lower competitiveness. Another problem is the fragmentation of holdings. According to the latest Census of Agriculture data, the average number of 
small plots per holding is 6, clearly indicating unviable land usage. In 2014 the Government of the Republic of Serbia started a process aimed at consolidating property over the land (Djuric et al., 2016). Consolidation assumes property rights resolution, stimulations for farmers to increase the size of their farm as well as better control of unplanned constructions in zones covered by consolidation processes. Coupled with other systemic measures such as financial and logistical support in the agricultural sector, consolidation would help increase productivity as was the case under the measures applied within the EU CAP mechanism. Experience of the CAP and the system of subsidies influenced the increase of the ownership size and percentage of land usage in the EEC and EU member states. In parallel with the reforms in the agricultural sector and the EU integration process, Serbia will have more opportunities to develop the agriculture sector through the EU's structural and investment funds. Some, like IPARD,${ }^{1}$ have just recently become accessible (2017), and some will be implemented as soon as Serbia becomes a full member of the EU.

Since all of the above-mentioned problems have a negative influence on the profitability of the agricultural sector, they are indirectly related to land prices. Prices in Serbia are considerably lower compared to the average price in post-communist states that entered the EU in 2004 and 2007. They are around 4 times lower compared to Slovenia and 2.3 times lower than in Poland (Graph 2). It is important to stress that joining the EU has been followed by a significant price increase in almost all of the observed countries. For example, compared to 2007, prices in Romania and Poland were 3.9 and 2.9 times higher respectively (Zubovic et al., 2016).

Figure 2. The average prices of agricultural land in 2015 (EUR/ha)

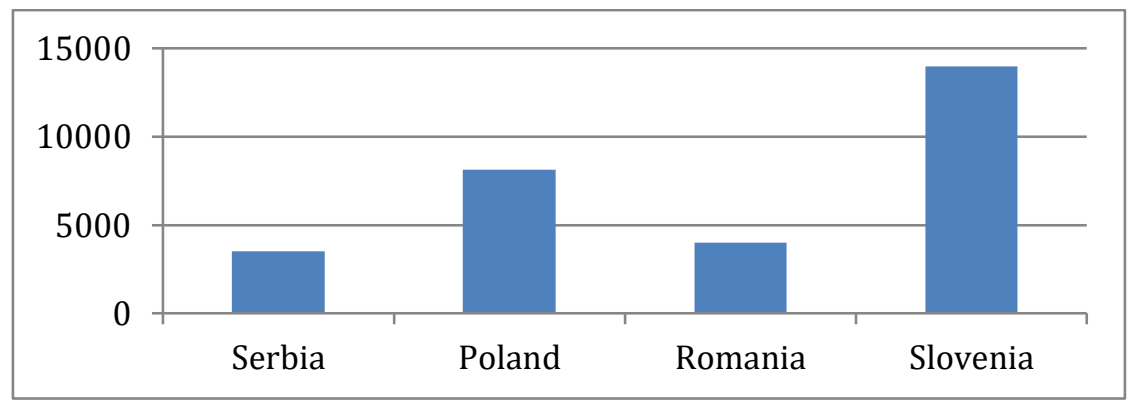

Source: Zubovic et al. (2016)

In Serbia, the prices of agricultural land depend mainly on the region and size of the land area, amounting from EUR 1,000 per hectare to EUR 12,000 per hectare in the plains of the province of Vojvodina. However, in the "old" EU member states, an extremely low supply of agricultural land results in prices which are above EUR 50,000 per hectare.

\section{Economic effects of agricultural land liberalisation and its implications on the status of domestic farmers in Serbia}

Economic arguments in favour of the liberalisation of agricultural land are mainly related to the achievement of more efficiency within the agricultural sector. The most important envisaged effects are as follows (Zubovic, 2016):

\footnotetext{
${ }^{1}$ See: https://ec.europa.eu/agriculture/enlargement/assistance/ipard_en
} 
- Increase of productivity

- Consolidation of the plots

- Increase of exports of agricultural products

- Increase in prices of the land

Realisation of the above-mentioned effects would also depend on the application of the rule of law and quality of the adopted institutional framework. Understanding how regulations affect the functioning of land sales and rental markets can help design informed policies to promote sustainable land management (Swinen et al., 2014). In the case of institutional deficiencies, policy instruments and technical solutions might produce adverse effects such as corruption and other forms of rent-seeking behaviour reducing economic efficiency, lowering government revenues and increasing income inequality. For these reasons, the institutional pre-requisites of proper decision making and implementation processes should be prioritised, investigating the relationships between proposed policy instruments and the emergence, strengthening or weakening of democratic and participatory institutions (Hagedorn, 2004). It is particularly difficult for policy makers to balance the level of interference. As Wegren argued focusing on the Russian experience during the 1990s, institutions and "the rules of the game" matter, and their design and impact are crucial in understanding behavioural responses during market reform. Policy makers needed to be aware that institutions would not magically appear following privatisation, and institutional outcomes were not wholly controllable from the centre (Wegren, 2012). For that reason the main focus of agricultural policies in developed countries is on keeping agricultural incomes high through the remuneration of social and environmental services offered to the public and through assistance in redirecting the activity towards other sectors tourism, commerce, artisanship, etc. (Sali, 2012).

Although liberalisation in general could have a favourable impact on competitiveness, its application should be gradual, given the potential problems arising from specific characteristics of the Serbian agricultural market and the interests of its small agricultural producers whose current number is 631,000 per last Census in 2014, which as mentioned earlier corresponds with 11 per cent of the total economically active population.

There are authors who have confirmed that potential benefits of full liberalisation surpass adverse effects for the local economy and fears often expressed by policy makers. According to them, the optimal solution is to choose an approach in favour of market liberalisation of agricultural land as a promising way to effectively use resource potentials (Zrybnieva and Zavolichna, 2017). However, within the current system in Serbia, market actors are still operating under information assimetry and institutional deficiencies, as well as unresolved ownership structure. Full and immediate liberalisation of property rights under these cirumstances might result in the situation that supply of the land will not be able to compensate for future price increases. The current reality of trade of agricultural land in Serbia sees small agricultural producers in a weak position, incable to compete with strong corporate investors on a financial and organisational level (MORS, 2014). Unresolved property rights represent significant limits on the supply side of agricultural land.

Systemic support for farmers in Serbia has still not been sufficiently developed. Agriculture is still not clearly seen as an attractive business. The State on the other hand has not provided adequate support in terms of subsidies and other financial and 
non-financial stimulative measures to small farmers. All of this limits local demand for agricultural land.

Another related issue regards land affordability. Given the considerably higher living standard and purchasing power in developed EU member countries, price pressures would result in a situation which almost prevents Serbian citizens from participating in the market. As presented in the Index of Affordability of Agricultural Land (Table 3 ), calculated as the ratio of the price of agricultural land and the Gross Value Added per employee in agriculture, forestry and fisheries in a specific country, local agricultural land is significantly more affordable to citizens in Serbia than or citizens in Poland, Romania and Slovenia which faced significant rise in land prices over the period of transition and after the EU accession. A similar trend could be expected for Serbia as well.

Table 3: Average price (in EUR) and affordability of the agricultural land Index in Serbia and selected EU countries

\begin{tabular}{|l|c|c|c|c|}
\hline Measure/Country & Serbia & Poland & Romania & Slovenia \\
\hline Affordability of land Index & 0.67 & 1.75 & 1.18 & 1.40 \\
\hline
\end{tabular}

Source: Zubovic et al. (2016)

On the other hand, if affordability of Serbian land to the citizens of other EU countries is considered, the data in Table 4 show that it is considerably more affordable to rich citizens of the "old" Europe. Those will probably support the pattern of market behavior discussed in the theoretical considerations within the first section of this paper. The supply of the Serbian market will represent additional supply that will satisfy existing demand in developed economies.

Table 4: Affordability of Serbian agricultural land for citizens of selected EU countries in 2015

\begin{tabular}{|c|c|}
\hline Country/Measure & Affordability of Land Index \\
\hline Serbia & 0.67 \\
\hline Poland & 0.75 \\
\hline Romania & 1.03 \\
\hline Slovenia & 0.35 \\
\hline Germany & 0.13 \\
\hline Netherland & 0.06 \\
\hline France & 0.08 \\
\hline Italy & 0.08 \\
\hline
\end{tabular}

Source: Zubovic et al. (2016)

Given the indicator values from Table 4, it should be noted that land in Serbia is less affordable to people in Serbia than in the case of land in Romania and Poland, compared in accordance with purchasing power approximated per gross value added per capita in agriculture. It is 5-10 times more affordable to the people of Germany, Netherlands, Italy or France.

In general, the most important potential economic effect of full liberalisation refers to the dynamic rise of agricultural land prices. It tends to occur due to rapid rise in demand resulting from the ability of foreign citizens to buy land and the expected increase of income from agriculture as a result of EU subsidies. The rise in price would be fueled additionally by factors due to supply limits such as the incomplete process of 
restitution and privatisation, undeveloped register of agricultural land and fragmented land ownership. Joining the EU, even without full liberalisation, is expected to increase pressure for price increases. Given the lower elasticity of supply when compared to demand for agricultural land, full liberalisation would have an additional impact on price increases and make land acquisitions for local citizens and farmers almost impossible (Lovrincevic and Vizek, 2009),

The experience of the Czech Republic, Hungary, Poland, Slovakia, Lithuania, Estonia and Latvia that joined the EU in 2004 and had restrictive approaches in terms of full liberalisation-has confirmed trends of high growth in yield, income and productivity of agricultural production. Despite trade restrictions, the price of land in these countries has been rising since joining the EU. This effect has been partly achieved due to greater subsidies for EU members. The transition period in the process of liberalisation has meant that adequate results and catch up process have been observed, particularly in productivity. The gradual approach has also seen a slight change of attitude among citizens towards the possibility of allowing foreign citizens to acquire land (MORS, 2014).

\section{Regulations concerning trade and property rights over agricultural land in the EU}

In the context of the legal regulations in the EU member states, acquis communitaire (EU regulative) is not of primary importance and consequently there is no legal basis for the EU competences with regard to property rights. More precisely, the Treaty on the Functioning of the EU (2009) contains a specific provision that defines the following: "Treaties (primary EU law) do not in any way affect the rules that Member States apply within the system of property rights”.

Member States as provided for in Article 345 of the Treaty have the right to: 'regulate the system of property rights' on their territory. This article does not envisage the introduction of provisions that would be contrary to the basic principles of the political and economic order of the European Union into their individual legal systems. On the other hand, the Treaty provides for certain prohibitions and restrictions on the legislation of individual members, which is explicitly stated in the following provision in relation to the integrity and unity of the scope of application of the Treaty: 'Within the scope of application of the Treaty and without prejudice to their specific provisions, any discrimination based on citizenship is prohibited'. It follows from the cited paragraph that the principle of non-discrimination applies referring to prohibition of discrimination against persons from other EU Member States based on their nationality.

The EU has recognised the specific nature of agricultural land. In its rulings on the acquisition of agricultural real estate, it has recognised a number of public policy objectives that can in principle justify restrictions on investment in agricultural land. These include (European Commission, 2017, p. 11):

- to increase the size of land holdings so that they can be exploited on an economic basis, to prevent land speculation

\footnotetext{
${ }^{2}$ Article 345 UFEU, Consolidated version of the Treaty on European Union and the Treaty on the Functioning of the European Union [2009] OJ C83/13.
} 
- to preserve agricultural communities, maintain a distribution of land ownership which allows the development of viable farms and management of green spaces and the countryside, encourage a reasonable use of the available land by resisting pressure on land, prevent natural disasters, and sustain and develop viable agriculture on the basis of social and land planning considerations (which entails keeping land intended for agriculture in such use and continuing to make use of it under appropriate conditions)

- to preserve a traditional form of farming of agricultural land by means of owner-occupancy and ensure that agricultural property be occupied and farmed predominantly by the owners, preserve a permanent agricultural community, and encourage a reasonable use of the available land by resisting pressure on land

- to maintain, for town and country planning or regional planning purposes and in the general interest, a permanent population and an economic activity independent of the tourist sector in certain regions

- to preserve the national territory within the areas designated as being of military importance and protect military interests from being exposed to real, specific and serious risks.

In most EU Member States, there are no specific restrictions at the national level regarding the access of foreigners from other Member States to the ownership of immovable property and, above all, agricultural land. This is the case in the following countries: Germany, France, UK, Italy and Spain. However, other EU Member States have imposed restrictions that include conditions for the possession of real estate: the existence of a customer's place of residence on the territory of that State; restrictions regarding the form or type of the real estate and the category of the buyer. Some EU Member States have restricted the acquisition of citizenship for persons who have a certain minimum amount of cash in the accounts of banks with headquarters in that country. A detailed list of restrictions which existed in new member states in 2010 is provided in Table 5 .

Table 5. Legal restrictions on the acquisition of agricultural land in the NMS

\begin{tabular}{|c|c|c|c|}
\hline Country & $\begin{array}{l}\text { Can EU citizens buy agricultural land } \\
\text { despite the restriction? }\end{array}$ & $\begin{array}{l}\text { Can a legal } \\
\text { entity buy } \\
\text { agricultural } \\
\text { land? }\end{array}$ & $\begin{array}{l}\text { Can a legal entity that is } \\
\text { registered in the country } \\
\text { but owned by foreigners } \\
\text { buy agricultural land? }\end{array}$ \\
\hline Bulgaria & $\begin{array}{l}\text { Yes, if they are self-employed agricultural } \\
\text { producers who wish to settle in Bulgaria and } \\
\text { are established }\end{array}$ & Yes & Yes \\
\hline $\begin{array}{l}\text { Czech } \\
\text { Republic }\end{array}$ & $\begin{array}{l}\text { Yes, } \\
\text { - if married to a Czech citizen } \\
\text { - if } \mathrm{s} / \text { he has been staying and farming in the } \\
\text { country for at least } 3 \text { years, then } \mathrm{s} / \text { he can buy } \\
\text { any parcel in the country }\end{array}$ & Yes & Yes \\
\hline Estonia & $\begin{array}{l}\text { Plots } 10 \text { ha: Yes, } \\
\text { - if married to an Estonian citizen } \\
\text { - if s/he has been staying and farming in the } \\
\text { country for at least } 3 \text { years, the particular plot } \\
\text { s/he has been renting can be bought }\end{array}$ & Yes & Yes \\
\hline Hungary & $\begin{array}{l}\text { Yes, } \\
\text { - if married to a Hungarian citizen } \\
\text { - if } \mathrm{s} / \text { he has been staying and farming in the } \\
\text { country for at least } 3 \text { years, the particular plot } \\
\mathrm{s} / \text { he has been renting can be bought }\end{array}$ & No & No \\
\hline
\end{tabular}




\begin{tabular}{|c|c|c|c|}
\hline Latvia & $\begin{array}{l}\text { Yes, } \\
\text { - if married to a Latvian citizen } \\
\text { - if } \mathrm{s} / \text { he has been staying and farming in the } \\
\text { country for at least } 3 \text { years, the particular plot } \\
\mathrm{s} / \text { he has been renting can be bought }\end{array}$ & Yes & $\begin{array}{l}\text { Yes, if a minority of the } \\
\text { shares are owned by } \\
\text { foreigners }\end{array}$ \\
\hline Lithuania & $\begin{array}{l}\text { Yes, } \\
\text { - if married to a Lithuanian citizen } \\
\text { country for at least } 3 \text { years, then s/he can buy } \\
\text { any parcel in the country }\end{array}$ & Yes & Yes \\
\hline Poland & $\begin{array}{l}\text { Plot }<1 \text { ha not located in border zones: Yes, } \\
\text { - if married to a Polish citizen and } \\
\text { - if residing in Poland for at least } 5 \text { years } \\
\text { Other plots: } \\
\text { - if married to a Polish citizen, and } \\
\text { - if s/he has been staying and farming in the } \\
\text { country for at least } 3 \text { years, the particular plot } \\
\text { s/he has been renting can be bought }\end{array}$ & Yes & $\begin{array}{l}\text { Yes, if a minority of the } \\
\text { shares are owned by } \\
\text { foreigners }\end{array}$ \\
\hline Romania & $\begin{array}{l}\text { Yes, if the person is an independent farmer } \\
\text { who wants to establish a residence in Romania } \\
\text { and can prove his/her ability to farm }\end{array}$ & Yes & Yes \\
\hline Slovakia & $\begin{array}{l}\text { Yes, } \\
\text { - if married to a Slovakian citizen } \\
\text { - if s/he has been staying and farming in the } \\
\text { country for at least } 3 \text { years, the particular plot } \\
\text { s/he has been renting can be bought }\end{array}$ & Yes & Yes \\
\hline Macedonia & Yes, if the individual inherits the property & Yes & Yes \\
\hline
\end{tabular}

Source: Swinnen et al. (2014)

It should be noted that regarding the acquisition of ownership of agricultural land, the new EU member states have developed and imposed certain restrictions on foreigners ability to purchase agricultural land for a number of reasons of which land affordability for local citizens has been the most important. Below are examples of specific regulations adopted by the EU Member States Poland and Hungary.

As part of the EU negotiations process, Poland introduced special status measures that limited the right of foreigners to buy agricultural land; these measures were to be in force for 12 years after joining the EU (Zubovic et al., 2016). Poland joined the EU on May 1, 2004; thus the special status period expired on May 1, 2016. However, before the expiry date, on April 30, 2016, a special Law on Agricultural Land ${ }^{3}$ came into force (Regulation 95/2017). Provisions of the law included a significant restriction on the right of citizens of other EU Member States to buy agricultural land.

Restrictions defined in Polish Law include the following conditions (Zubovic et al., 2016):

1. a moratorium of 5 years for sale of state-owned land is introduced;

2. for private land, the following restrictions are introduced:

- only farmers can buy;

- the buyer must be obliged to process the land for the next 10 years;

- agricultural land area sold could not be more than 1oha in size.

Another example of limiting the right to purchase agricultural land is Hungarian legislation, which relates de facto to restrictions for persons outside the EU. The Basic

\footnotetext{
3 Available at: http://bip.kowr.gov.pl/informacje-publiczne/zarzadzenia-dyrektora-generalnego/zarzadzenie-nr95-2017-z-dyrektora-generalnego-krajowego-osrodka-wsparcia-rolnictwa-z-dnia-6-pazdziernika-2017-roku-wsprawie-wykonywania-umowy-dzierzawy-nieruchomosci-zasobu-wlasnosci-rolnej-skarbu-panstwa
} 
Law of Hungary, states that 'the purchase and sale of land and forests will be regulated by a special law of exceptional significance' and refers to the provision of the Land Law. The Hungarian Land Law of 2013 (Law No. CXXII) states in Article 9 that 'a foreign person can not acquire ownership of agricultural land' greater than 1 hectare. From the text of the law it can be concluded that the term 'foreign person' refers only to 'nationals of non-EU, EEA or other states that enjoy the same status under an international agreement' (Article 5, paragraph 15). The interpretation of the aforementioned legislation indicates that foreigners from other EU countries in Hungary can acquire property of agricultural land. When it comes to foreigners from other countries, the restrictive provision of Article 9 of the law is relatively easy to avoid, since all foreigners can buy or establish legal entities in accordance with domestic law.

\section{The provisions of the Stabilisation and Association Agreement (SAA) of importance for the acquisition of ownership of immovable property by citizens of EU member states}

The Stabilisation and Association Agreement (SAA) was signed between the Republic of Serbia and the European Union on 29 April 2008 (SAA, 201). It envisaged Serbia's obligation to harmonise legislation of the Republic of Serbia to the EU and to ensure the creation of a free trade area between the EU and Serbia after a transitional period of 6 years. 4 The key provision of the SAA regarding the issues of acquiring property rights over real estate in the territory of Serbia is defined in Article 63, paragraph 2. Overall, the following paragraph is of special importance concerning the trade in agricultural land:

Upon the entry into force of this Agreement, Serbia will allow citizens of the Member States of the European Union to acquire ownership of immovable properties in Serbia, with the full and effective implementation of existing procedures. In the period of four years from the date of entry into force of this Agreement, Serbia will gradually harmonise its legislation regarding the acquisition of property over real estate in Serbia in order to provide the citizens of the European Union with the same treatment as their citizen.

This article stipulates that within a period of 4 years from the date of entry into force (2013) of the agreement, citizens of the EU Member States shall be entitled to acquire, without any discrimination in relation to the citizens of Serbia, rights over immovables in Serbia. Acquisition of property rights over residential buildings, apartments and other similar immovables has not been limited to EU citizens in the meantime. The concept of real estate included, in addition to construction objects, agricultural land as immovable property as well. The period of four years expired on September 1, 2017, at which time the right for foreign natural persons to acquire ownership rights over agricultural land was supposed to enter into force.

In the meantime, before that deadline, in August 2017, the Government of the Republic of Serbia proposed amendments to the Agricultural Land Act (Republika Srbija, 2018) whose provisions created obstacles for citizens of other EU countries to acquire property over agricultural land. The Law states that citizens of an EU Member State, in accordance with the SAA, can acquire an agricultural land property right through a

4 The Agreement is available in full at: http://www.mei.gov.rs/upload/documents/sporazumi_sa_eu/saa_textual_part_en.pdf 
legal business for a fee or without compensation under certain conditions defined in the Law.

The restrictions are defined in Article 72 and set out the following:

- a person who buys agricultural land must be permanently settled in the local community (municipality) on whose territory the agricultural land is located;

- a person must fulfill the condition that he has been processing for at least three years the land that is the subject of the sale;

- the natural person who buys agricultural land must have a registered agricultural holding which is commercially active;

- a person owns equipment and machinery for performing agricultural production.

In addition to the above restrictions, there are additional restrictions including:

- the object of sale to foreign persons can be only agricultural land that is privately owned;

- prohibition of the sale of land as agricultural if the actual purpose is construction;

- land is not located in the zone of protected natural assets;

- does not interfere with military installations, facilities or complexes and is not located in land zones of security;

- it is not located in a zone $10 \mathrm{~km}$ from the state border.

A specific restriction relates to the maximum land area that a foreign citizen can buy, i.e. it is limited to a maximum of 2 hectares of agricultural land. The Republic of Serbia has the preemptive right to purchase agricultural land that is in private ownership and is the subject of sale. Agricultural land in state ownership cannot be alienated or sold apart from exceptions outlined in Art.72 of the Law.

In summary, the framework of the process of Serbia's accession to the EU, in terms of the freedom of movement of certain economic factors, the picture is as follows:

Table 6: Summary: Freedom of movement of certain economic factors

\begin{tabular}{|l|c|c|c|}
\hline \multicolumn{1}{|c|}{ Economic factor } & Free movement & Movement restrictions & Restricted \\
\hline Establishment of companies & $*$ & & No \\
\hline Goods & $*$ & & No \\
\hline Financial capital & $*$ & & No \\
\hline Labour force & & $*$ & $*$ \\
\hline Construction objects & $*$ & $*$ & $*$ \\
\hline Agricultural land & $*$ & & \\
\hline Tax treatment differences & $*$ & & \\
\hline
\end{tabular}

Hence, despite its obligation to do so by the SAA of 2008, Serbia has so far - like other post-communist states which joined the EU in and after 2004 - avoided (fully) liberalising the trade of agricultural land. As was the case in Poland, Hungary and other former transition countries, the reasons behind it are primarily related to affordability of agricultural land to local farmers and citizens in the presence of strong international competition, unresolved ownership issues and socio-political stability, mainly related to depopulation in some parts of the country which could be acerbated by full and 
immediate liberalisation. Furthermore, land grabbing as one of the potential effects of full liberalisation of the property rights transfer is related to severe risks in terms of change of agricultural production structure, including food safety and security (Ciutacu et al., 2017). For all of the aforementioned reasons, full liberalisation of the trade in agricultural land in Serbia will probably not take place, at least not until the completion of the EU accession process. Therefore, it is more likely that the Serbian government will apply a transitional model, allowing land acquisitions by foreign citizens under strict legal and economic conditions.

\section{Concluding remarks and policy recommendations}

Liberalisation of property rights over agricultural land within the EU is a common goal. There are a number of legal and socio-political constraints and obstacles that prevent the free circulation of the ownership of agricultural land within EU member states. Liberalisation is expressed in concentric circles from the centre of the developed, "old" EU member states, to the periphery of the countries that became members in the last decade. Serbia, as a country in the waiting room for EU accession, has liberalised its commodity and capital markets, but has still not implemented liberalisation of the agricultural land market. For EU citizens, but not for EU companies, the free transfer of ownership over agricultural land is still limited.

According to The Stabilisation and Association Agreement (SAA), signed by the Republic of Serbia and the European Union in 2008, Serbia was obliged to apply full liberalisation by September 2017, although this has not been the case with other candidate countries. The Serbian Government did not have a consistent evidencebased ownership and agricultural policy. However, in 2017 full liberalisation was prevented through the introduction of certain laws and foreign citizens are still not allowed to acquire agricultural land in Serbia. The authors of the paper argued in favour of this decision because otherwise to the Serbian agricultural sector might face significant problems and serious challenges related to unresolved ownership and restitution issues as well as lack of a consistent agricultural policy. Full liberalisation would put strong pressures on the demand side, resulting in strong price increases. For that reason, local farmers and other citizens would not be able to afford agricultural land in the presence of strong international competition. The experience of other EU candidate countries that limited transfer of property rights in a transition period confirmed the rationality of this approach. In terms of future policy, there are several options to prevent immediate exposure of Serbian agricultural land to international competition, at least prior to entering the EU. These options mainly relate to the adoption of a number of measures which would prevent speculative transactions, ensure agricultural production is sustained, limit the size of property that can be acquired, and ensure reciprocity for Serbian citizens. Application of the aforementioned conditions should be coupled with further strengthening of the institutions, rule of law and resolving present legal uncertainties.

\section{Bibliography}

Antonelli, M., Siciliano, G., Turvani, M. E., \& Rulli, M. C. (2015). Global investments in agricultural land and the role of the EU: Drivers, scope and potential impacts. Land Use Policy. 47 (September), pp. 98-111.

Becker, G. S. (1964). Human capital theory. Columbia, New York, 1964. 
Blacksell, M., \& Born, K. M. (2002). Private property restitution: the geographical consequences of official government policies in Central and Eastern Europe. Geographical Journal. 168(2), 178-190.

Bogdanov, N. L., Đorđević-Milošević, S., \& Clark, L. (2007). Mala ruralna domaćinstva u Srbiji i ruralna nepoljoprivredna ekonomija. UNDP.

Boros, T. (2015). Hungarian land as political instrument, Friedrich-Ebert-Stiftung Budapest (available at: http://library.fes.de/pdf-files/bueros/budapest/12145.pdf).

Constantin, C., Luminița, C., \& Vasile, A. J. (2017). Land grabbing: A review of extent and possible consequences in Romania. Land Use Policy. 62 (March), 143-150.

Djukic, P. (2017). Održivo gospodarenje zemljišnim resursima u svetlu odocnelih ekonomskih reformi. Beograd: Institut ekonomskih nauka.

Djuric, K., Milovic, S., Hyba, H. H. H., Prodanovic, R., \& Boskovic, J. (2016). Comparative analysis of agricultural farms property structure in the Republic of Serbia and EU. Ekonomija: teorija i praksa. 9 (2), 19-32.

Djuricin, S., Beraha, I., \& Djukic, M. (2013). The impact of climate extremes on agricultural output in the Republic of Serbia. Ecologica: nauka, privreda, iskustva. 20 (72), pp. 587-592.

Draskovic, B. (1998). Ekonomija prirodnog kapitala, vrednovanje i zaštita prirodnih resursa. Beograd: Institut ekonomskih nauka.

Drašković, B., Rajković, Z., \& Bodroža, D. (2011). Policy of small farms subsidizing in the function of economic and social development of villages in Serbia. Beograd: Institut ekonomskih nauka (available at: http://ebooks.ien.bg.ac.rs/159/valuing ecosystem services).

European Commission (2017). Commission Interpretative Communication on the Acquisition of Farmland and European Union Law, Official Journal of the European Union, C 350/5.

Eurostat (various years). European Union Statistics (available from: http://epp.eurostat.ec.europa.eu)

Export.gov (2018). Serbia - Agriculture (available at: https://www.export.gov/article?id=Serbia-Agribusiness).

Gajić, T., Vujko, A., Cvijanović, D., Penić, M., \& Gagić, S. (2017). The state of agriculture and rural development in Serbia. R-Economy. 3 (4), 196-202.

Hagedorn, K. (2004). Property rights reform on agricultural land in Central and Eastern Europe. Quarterly Journal of International Agriculture. 43 (4), pp. 409-438.

Hertel, W. T., Baldos, C. L. U. Global Change and the Challenges of Sustainably Feeding a Growing Planet. Heidelberg, New York, Dordrecht, London: Springer International Publishing. 
Hodgson, S., Cullinan, C., \& Campbell, K. (1999). Land Ownership and Foreigners: A Comparative Analysis of Regulatory Approaches. FAO Legal Papers Online (available at: https://peacepalacelibrary.nl/ebooks/files/lpo6.pdf).

Humblet, F. (2013). Foreign land ownership: Why are the Polish and Hungarian measures in discrimination with EU citizens'right to acquire agricultural land within the European Union? MaRBLe, 4.

Kuzman, B., Djurić, K., Mitrović, L., \& Prodanović, R. (2017). Agricultural budget and agriculture development in Republic of Serbia. Economics of Agriculture. 64(2), pp. 515-531.

Laroche, M., Mérette, M., \& Ruggeri, G. C. (1999). On the concept and dimensions of human capital in a knowledge-based economy context. Canadian Public Policy/Analyse de Politiques. 25 (1), pp. 87-100.

Lavigne, M. (1999). The economics of transition: from socialist economy to market economy. Houndmills, Basingstoke and New York: Palgrave, 2nd ed. (first ed. 1995).

Lovre, K., Lovre, I. (2017). Akvizicije poljoprivrenog zemljišta u međunarodnim razmerama: implikacije na prehrambenu sigurnost $i$ ruralno siromaštvo. Beograd: Institut ekonomskih nauka.

Lovrinčević, Ž., \& Vizek, M. (2009). Poljoprivredno zemljište u novim zemljama članicama EU iu Hrvatskoj: cijene, priuštivost i konvergencijski potencijal. Ekonomski pregled. 60 (1-2), pp. 28-49.

MORS (2014). Sporazum o stabilizaciji i pridruživanju i obaveze Srbije u domenu liberalizacije kretanja kapitala odnosno trgovine poljoprivrednim zemljištem. Analiza potencijalnih problema i predložena rešenja, (available at: http://eukonvent.org/wpcontent/uploads/2015/o3/SSP-i-trgovina-poljoprivrednim-zemljistem.pdf).

Parausic, V., Cvijanovic, D. (2014). Ekonomska veličina poljoprivrednih gazdinstava u Srbiji i preporuka mera za njihovo osnaživanje. Zbornik radova. Republički zavod za statistiku, 25-62.

Plantinga, A. J., Lubowski, R. N., \& Stavins, R. N. (2002). The effects of potential land development on agricultural land prices. Journal of urban economics, 52(3), 561-581.

Republika Srbija, (2017), Zakon o poljoprivrednom zemljištu,. Sluzbeni glasnik Republike Srbije, br.62/2006; 65/2008; 41/2009; 112/2015 i 80/2017 (avaiable at: accessible at: https://www.paragraf.rs/propisi_download/zakon_o_poljoprivrednom_zemljistu.pdf).

Sali, G. (2012). Agricultural Land Consumption in Developed Countries. In 2012 Conference, August 18-24, 2012, Foz do Iguacu, Brazil (No. 126431). International Association of Agricultural Economists.

Simonovic, Z., Mihailovic, B., \& Curcic, N. (2017). Structure of agricultural distributions in the Republic of Serbia, by the surface of agricultural land. Poslovna ekonomija. 11 (2), pp. 247-259. 
Statistical Office of the Republic of Serbia (2012). Agricultural census (avaiable at: http://www.stat.gov.rs/en-us/oblasti/poljoprivreda-sumarstvo-i-ribarstvo/popispoljoprivrede).

Swinnen, J. and L. Vranken (2007). Review of Transitional Restrictions on Agricultural Real Estate for Foreigners in the New EU Member States, CEPS Publications.

Swinnen, J., Van Herck, K., \& Vranken, L. (2014). Land market regulations in Europe. LICOS Discussion Paper Series. Discussion Paper 354/2014.

UFEU, (2008). Consolidated version of the Treaty on European Union and the Treaty on the Functioning of the European Union, OJ C83/13.

Vehapi, S., \& Šabotić, Z. (2015). The state and problems of Serbian agriculture. Economics of Agriculture, 62(1), 245-257.

Wegren, S. K. (2012). Institutional impact and agricultural change in Russia. Journal of Eurasian Studies, 3(2), 193-202.

Republika Srbija, (2018), Zakon o poljoprivrednom zemljistu, Sluzbeni glasnik Republike Srbije, br. 62/2006, 65/2008 - dr. zakon, 41/2009, 112/2015 i 80/2017), available at: https://www.paragraf.rs/propisi_download/zakon_o_poljoprivrednom_zemljistu.pdf, accessed at: July 27, 2018.

Zrybnieva, I., \& Zavolichna, T. (2017). Perspectives to the Liberalization of the Agricultural Land Market in Ukraine. Baltic Journal of Economic Studies, 3(2).

Zubović, J., Subić, J., Rajnović, L., Paraušić, V., Bodroža, D., Jeločnik, M., \& Mitić, P. (2016). Analiza pravnog i institucionalnog okvira tržišta poljoprivrednog zemljišta, procena ekonomskih efekata liberalizacije tržišta poljoprivrednog zemljišta i preporuke za izmene domaćeg zakonodavnog i institucionalnog okvira i njihovu adekvatnu primenu: u okviru projekta. Analitička podrška pregovorima sa EU. Ecologica: nauka, privreda, iskustva. 24 (88), pp. 886-889. 